\title{
"A Tissue of the most Flagrant Anomalies": Smallpox Vaccination and the Centralization of Sanitary Administration in Nineteenth-Century London
}

\author{
GRAHAM MOONEY*
}

Histories of smallpox and vaccination are both varied and voluminous. In purely epidemiological terms, smallpox has acquired for itself a position of significance far in excess of its numerical importance as a cause of death in the nineteenth century. ${ }^{1}$ Although mortality from the disease had already declined from high levels in the eighteenth century, smallpox vaccination has recently been credited for a large part of the total mortality decline in England and Wales during the second half of the nineteenth century. ${ }^{2}$ While vaccination was undoubtedly the prime facilitator for the eradication of smallpox, recent research has shown that the regional pattern of public infant vaccination take-up rates varied enormously across the country and over time, and that revaccination at puberty was not universal. ${ }^{3}$ In wider terms, vaccination also addresses important historical debates, including the state provision of free, universal (though compulsory) health care. ${ }^{4}$ It helps illustrate the success of local preventive medical services; ${ }^{5}$ and it draws attention to ideological objections to governmental interference with individual liberty-in this respect smallpox and vaccination have prompted comparison with the present-day AIDS

*Graham Mooney, PhD, Centre for Metropolitan History, University of London, Senate House, Malet St, London WC1E 7HU.

The work for this paper was initially funded by an ESRC Research Competition Award. Research on London is continuing with a project grant from the Wellcome Trust, 'Mortality in the Metropolis, 1860 - 1920' (grant number 044175), based at the Centre for Metropolitan History. A number of colleagues have commented on earlier versions of the article, including those present at a BSPS symposium on early childhood mortality. I would also like to thank in particular Bill Gould, Anne Hardy, Violetta Hionidou, Gerry Kearns, Bill Luckin, Andrea Tanner, Naomi Williams, Bob Woods and Bill Bynum and three anonymous referees for Medical History.

\footnotetext{
${ }^{1}$ Even during the final major epidemic in England and Wales (1871-72), smallpox claimed a total of only 4.2 per cent of all national deaths. These figures are calculated from the 34th and 35th Annual Reports of the Registrar-General (henceforth ARRG), 1871 and 1872.

$2 \mathrm{~J}$ Landers, Death and the metropolis: studies in
}

the demographic history of London 1670-1830, Cambridge University Press, 1993, ch. 3; A Mercer, Disease, mortality and population in transition: epidemiological-demographic change in England since the eighteenth century as part of a global phenomenon, Leicester University Press, 1990, p. 157; P E Razzell, The conquest of smallpox, Firle, Sussex, Caliban, 1977.

${ }^{3} \mathrm{~N}$ Williams, "The implementation of compulsory health legislation: infant smallpox vaccination in England and Wales, 1840-1890', J. hist. Geogr. 1994, 20: 396-412.

${ }^{4} \mathrm{R}$ Lambert, 'A Victorian National Health Service: state vaccination $1855-71$ ', The hist. J., 1962, 5: 1-18; R G Hodgkinson, The origins of the National Health Service, London, Wellcome Historical Medical Library, 1967, pp. 28-31; R M MacLeod, 'Law, medicine and public opinion: the resistance to compulsory health legislation 1870-1907. Parts I and II', Public Law, 1967: 107-28 and 189-211.

5 A Hardy, The epidemic streets: infectious disease and the rise of preventive medicine, 1856-1900, Oxford University Press, 1993, pp. 110-50. 


\section{Graham Mooney}

epidemic. ${ }^{6}$ This paper provides a different perspective and demonstrates how a study of the chaotic administrative arrangements for vaccination in the capital-which frequently led to calls for a single sanitary authority in London-may fit into historical assessments of central-local relations in nineteenth-century government. It complements earlier research into medico-political history, where outbreaks of severe epidemic disease, cholera in particular, have allowed valuable insights into the ability of administrative structures to manage periods of extreme social stress and dislocation. ${ }^{7}$ Using the Reports of the medical inspectors of the Privy Council and its successor the Local Government Board (LGB), and data from the annual Reports of the Registrar-General, the paper draws together epidemiological, political, legislative and administrative evidence to show how the inadequacy of the spluttering smallpox vaccination machine in London was primarily responsible for the capital's comparatively high levels of smallpox mortality in the third quarter of the nineteenth century. The hapless implementation of, and in some instances blatant disregard for, legislation, and the debilitating association of vaccination with the Poor Law, will be assessed. Whilst presenting a highly focused study of a specific form of public health intervention, this article also directs attention to altogether larger historiographical issues. The first of these is the extreme difficulty experienced both by contemporaries and historians in arriving at a suitable definition of "sanitary" London. The second relates to the problem of London government-in other words, how it was that the sheer scale and complexity of the capital and its constituent parts could be managed and reformed. As it still does today, this latter theme generated passionate debate throughout the second half of the nineteenth century and the paper further illustrates why solutions that were essentially "medical" in conception were seen to be required for a problem that was essentially political in practice.

\section{The Structure of Sanitary Government in London, 1855-88}

Between the years 1858 and 1873, the letters of William Farr to the Registrar-General, published in the latter's annual Reports, contained a section dealing specifically with the population trends of London. ${ }^{8}$ Farr used the capital as a model to exhort local action in sanitary matters as a means of reducing excessive urban mortality rates. It appears that this strategy of censorship, which simply involved, "mentioning the places which are chargeable with negligence, and exposing the culprits of the world", 9 may have worked well, but that the desired effect would have been greater if London's system of sanitary

\footnotetext{
${ }^{6} \mathrm{D}$ Porter and R Porter, 'The enforcement of health: the British debate', in E Fee and D M Fox (eds), AIDS: the burdens of history, Berkeley, University of California Press, 1988, pp. 97-120.

${ }^{7} \mathrm{R}$ J Evans, Death in Hamburg: society and politics in the cholera years, 1830-1910, Oxford University Press, 1987, pp. 218-26; G Kearns, 'Cholera, nuisances and environmental management in Islington, 1830-55', in W F Bynum and R Porter (eds), Living and dying in London, Medical History Supplement No. 11, London, Wellcome Institute for the History of Medicine, 1991.
}

\footnotetext{
${ }^{8}$ William Farr was appointed to the staff of the General Register office in 1839, where he served successively as the Compiler of Abstracts and then Superintendent of the Statistical Department until his retirement in 1880 . For a detailed history of his life and works, see J M Eyler, Victorian social medicine: the ideas and methods of William Farr, Baltimore, Johns Hopkins University Press, 1979.

${ }^{9}$ The Times, 7 August 1861.
} 


\section{Smallpox Vaccination in Nineteenth-Century London}

government had been centralized. Writing in 1886, the Medical Officer of Health (MOH) for Brighton reflected that "we in the provinces naturally look to London to take the lead in all matters belonging to sanitation or in connection with the sanitary service ... When the local government of London is placed on a uniform basis or plan, and thoroughly reorganized, from the example of London we shall look for great things in the extension of the science and practice of sanitation". ${ }^{10}$ According to Edwin Chadwick-an arch centralizer-London's disunity of government, "retarded improvement, diminished efficiency, and increased cost in every branch of local services", ${ }^{11}$ and the Sanitary Record described the capital's system of local government as "a tissue of the most flagrant anomalies and the most rampant red tape". ${ }^{12}$ The problem was twofold. First, there was a bewildering multiplicity of governing bodies. Second, the sanitary law in London remained unconsolidated, largely because the notion of such a merger aroused strong opposition among the independent sanitary authorities in the capital. A combination of the fragmentary executive and equally fragmentary legislation resulted in disjointed sanitary management.

London was exempted from the Municipal Corporations Act of 1835, a squandered opportunity that Robson has claimed was "a revolution missed ... from this calamity the metropolis has never recovered". ${ }^{13}$ The executive management of public health administration, and the legislation which empowered the executive bodies, therefore evolved in a piecemeal manner. Under the Metropolis Local Management Act of $1855,{ }^{14}$ the local sanitary government of London was controlled by 23 parish vestries and 15 combinations of parishes called district boards. The City of London, governed by the City Corporation which comprised 206 annually elected Common Council Members and 26 Aldermen elected for life, maintained its ancient privileges. Through its Commission of Sewers, the Corporation carried out virtually the same public health functions as the vestries and district boards. From 1867, hospital provision and admissions of pauper cases of infectious disease-commonly typhus, typhoid, scarlet fever and smallpox-were administered by the Metropolitan Asylums Board (MAB). ${ }^{15}$ Until the creation of the London County Council (LCC) in 1888, further powers for the enforcement of sanitary control were vested in the Metropolitan Board of Works (MBW), which was responsible for, among other things, the main drainage of the capital. ${ }^{16}$ Significantly in the context of this paper, control of vaccination administration rested with the local Poor Law Boards of Guardians. It is hardly surprising that little coherent policy was forthcoming from such a varied palimpsest of local bureaucracies. The parochial authorities in particular suffered

${ }^{10} \mathrm{R}$ P B Taaffe, 'Various topics in public medicine', Br. med. J., 1886, ii: 316-19, p. 319.

${ }^{11}$ E Chadwick, 'London centralized', Contemp. Rev., June 1884, p. 794.

${ }^{12}$ Editorial, 'Sanitary mismanagement in the metropolis', Sanit. Rec., 15 September 1886, NS 8: 117.

${ }^{13}$ An Act to Provide for the Regulation of Municipal Corporations in England and Wales 1835 (5 \& 6 Wm. IV c. 76). W A Robson, The government and misgovernment of London, London, George Allen and Unwin, 1939, p. 21. The Act created municipal boroughs outside London.

\footnotetext{
${ }^{14}$ Metropolis Local Management Act 1855 (18 \& 19 Vict. c. 120).

15 The Metropolitan Poor Act 1867 (30 Vict. c. 6).

${ }^{16}$ Chadwick reserved particular venom for the MBW, a creation of Benjamin Hall's Metropolis Local Management Act 1855 (see note 14 above), which he believed had destroyed the opportunity for unity in sanitary management. S E Finer, The life and times of Sir Edwin Chadwick, London, Methuen, 1952, pp. 504-5.
} 


\section{Graham Mooney}

criticism for their obduracy in sanitary matters, even from their employees, the MOHs. In 1860 Edwin Lankester, the MOH for St James Westminster, was scathing in his condemnation of the vestries and district boards: "it has been the usual course of action in England to give the power of superintending the sanitary welfare of the population to the local authorities in the towns and parishes, but the remark applies very generally to these bodies, that they are acquainted with the value of almost everything better than the value of human life". ${ }^{17}$ When local sanitary authorities should have been first past the post in devising and implementing housing regulations, supplying gas and water, and providing drainage and lighting services, William Farr at the GRO argued that the Corporation of London and the "half trusted vestries" deserted their responsibilities and the "field was left open to capitalists". He mused:

If the whole of the people amounting in 1871 to $3,885,641$ on a circle with a radius of 15 miles can be administered for police purposes from Scotland Yard, can they not be associated together in one community for the purpose of local government, and with the City for the central point of administration? A city is a Co-operative Society for the supply of the common wants. ${ }^{18}$

During the nineteenth century and up to the present day, wide debate has centred around the conflict between central and local government. ${ }^{19}$ Although the majority of research has concentrated upon the relationship between London and the provinces, London itself has also been difficult to ignore as an arena for the study of central-local relations. ${ }^{20}$ Yet the role of sanitary management in these debates has been somewhat marginalized against the need to provide a much wider assessment of a unified political administration of the capital. ${ }^{21}$ In the 1870 s, Farr argued that sanitary government in the capital should have been placed "under the supreme control of one Municipality, with a great administrator at its head". 22 Such a sweeping solution to London's problems may be considered startlingly simple yet radical; so radical, in fact, that eight legislative attempts to revamp London's governmental structure between 1860 and 1884 failed. Most of them encountered opposition because they proposed completely to supersede the vestries and the City Corporation with a unified authority. ${ }^{23}$ From the public health perspective, a compromise arrangement was frequently aired in the pages of the Sanitary Record during the early- to mid-1880s. It appears that the metropolitan MOHs generally favoured retaining the

\footnotetext{
${ }^{17}$ E Lankester, 'Notes on recent sanitary legislation in the Metropolis', Trans. Natn. Ass. Promotion Soc. Sci., 1860, pp. 666-75, pp. 667-8. L Parkes, 'London vestries, and the administration of sanitary law in the metropolis, Part I', Sanit. Rec., 15 April 1886, NS 7: 474-77, p. 477. Cf. T Orme Dudfield, 'Metropolitan sanitary administration', Sanit. Rec., 15 November 1883, NS 5: 235-40, p. 237 , who argued that although the vestries were, "much-abused bodies", their labours had "made London to be the best paved, the cleanest, the best lighted, the best drained, and, may we not say, the healthiest city in the world".

${ }^{18}$ 35th ARRG, 1872, op. cit., note 1 above, p. li.

${ }^{19} \mathrm{C}$ Bellamy, Administering central-local relations, 1871-1919: the Local Government Board in its fiscal and cultural context, Manchester
}

\author{
University Press, 1988; E P Hennock, 'Central/local \\ relations in England: an outline 1800-1950', Urban \\ Hist. Yb., 1982: 38-49; and R Lambert, 'Central and \\ local relations in mid-Victorian England: the Local \\ Government Act Office, 1858-72', Victorian Stud., \\ 1962, 6: 121-50. \\ $20 \mathrm{~J}$ Davis, Reforming London. The London \\ government problem, 1855-1900, Oxford, Clarendon \\ Press, 1988; and D Owen, The government of \\ Victorian London 1855-1889, ed. R MacLeod, \\ Cambridge, Mass., Belknap Press, 1982. \\ 21 The main exception being, $K$ Young and $P$ L \\ Garside, Metropolitan London, politics and urban \\ change 1837-1981, London, Edward Arnold, 1982, \\ especially chs 2 to 4 . \\ 22 35th ARRG, 1872, op. cit., note 1 above, p. li. \\ ${ }^{23}$ Robson, op. cit., note 13 above, pp. 71-3.
}




\section{Smallpox Vaccination in Nineteenth-Century London}

vestries in an executive capacity, but under the guiding control of a central authority. Such an authority would take over the work of the MBW; be responsible for hospital provision; have power to acquire the property of the water companies on equitable terms; and appoint coroners and registrars of births, deaths and marriages. Further, in wresting control of hospital provision and admission as well as smallpox vaccination from the MAB and Poor Law Guardians, it was hoped that the "pauperizing" nature and wary public perception of this association would be removed. It had long been contended that connection with the Poor Law Board in vaccination matters was both unwanted and inefficient, ${ }^{24}$ and that the responsibility for vaccination should be placed in the hands of the MOHs, who would be better placed to use vaccination as "one of the most useful weapons for the defence of the public health". ${ }^{25}$ This dissociation would potentially accrue wider public benefits in that no distinction would be made between paupers suffering from infectious disease and other members of the population who could not be properly treated in their homes. In other words, the preventive medical profession recognized the value of non-means-tested accessibility to health care, since "danger to the community is the same, be the patient who he may". ${ }^{26}$ The creation of a public health department, with a principal medical officer at its head, would have been a pre-requisite of the new authority. The department would effectively monitor and control the spread of disease through a network of local MOHs, the appointment of which would at least be confirmed, if not made, by the central authority. These MOHs would be responsible for making daily and periodic returns of sickness and mortality to the centre. It was suggested that some members of this central body could be elected by the vestries but that others would be elected directly by the ratepayers. This plan, it was hoped, would simultaneously ensure that the vestries would "be weeded of traders in insanitary property" and bring "irresponsible bodies to a condition of supervision". ${ }^{27}$ Further, the bitter pill of creeping centralization could be sweetened for the vestries by the promise of their retaining a degree of power and control over their local areas. But, perhaps most significantly from the medical viewpoint, with the centralization not only of administration, but also of knowledge, the plan would have given unbridled power to the MOHs as gatekeepers to the continuum of prevention, treatment, care and cure in London. The following sections of the paper show how this argument, which embraced the rationalization of vaccination and other public health services, developed and why it was not incorporated into the mainstream calls for the centralization of all sanitary services.

\section{Smallpox Mortality and the Structure of Vaccination Administration in Mid-Nineteenth-Century London}

Figure 1 shows the smallpox mortality rates for England and Wales and London, as well as London's share of the national total of smallpox deaths. ${ }^{28}$ Compared to England and Wales, London suffered generally from high smallpox mortality rates after the

\footnotetext{
${ }^{24} \mathrm{E}$ C Seaton, 'On public vaccination in England and Wales', Trans. Natn. Ass. Promotion Soc. Sci., 1857: 460-73, pp. 469-70.

25 Editorial, 'Vaccination and smallpox mortality', Sanit. Rec., 28 June 1878, 8: 406.

${ }^{26} \mathrm{~L}$ Parkes, 'London vestries, and the
}

administration of sanitary law in the metropolis, Part II', Sanit. Rec., 15 April 1886, NS 7: 532-34, p. 534.

${ }^{27}$ Ibid., pp. 532-3.

28 The population at risk used to calculate these mortality rates is the mean population given in the two censuses either side of any given date. For 


\section{Graham Mooney}



Source: Annual Reports of the Registrar-General

Figure 1: Total (all ages) smallpox mortality rates in England and Wales and London, and London's percentage share of national smallpox deaths, 1851-1901



Source: Annual Reports of the Registrar-General

Figure 2: Early childhood and total (all ages) smallpox mortality rates in London, 1851-86 


\section{Smallpox Vaccination in Nineteenth-Century London}

introduction of compulsory vaccination in $1853 .{ }^{29}$ During the first year of the 1871-72 epidemic, when there was a total of 23,126 smallpox deaths nationally, London's mortality rate was double the national one. ${ }^{30}$ Figure 1 also shows that London's share of national smallpox deaths rose above 70 per cent in the period 1878-81, although it must be remembered that the number of deaths nationally in these four years was low compared to epidemic years $(978,283,339$ and 1,673 smallpox deaths respectively). Figure 2 illustrates that children, and infants in particular, were especially vulnerable to the ravages of smallpox, most notably during periods of high overall mortality from the disease. ${ }^{31}$ Infant smallpox mortality rates in 1871 reached 1,006 per 100,000 live births, compared to a total smallpox mortality rate of 224 per 100,000 population.

In 1881 Shirley Murphy, MOH for St Pancras, outlined the manifold reasons for London's high levels of smallpox mortality in the 1870s and 1880s: the migratory character of the population, with newly arrived inhabitants from rural areas and abroad being unvaccinated; ${ }^{32}$ the large number of infants born in institutions escaping vaccination; the laxity of re-vaccination; and the difficulty of supplying lymph to the capital, especially during epidemics. ${ }^{33}$ To these, we may add the inefficient performance of the vaccination operation itself, which had already been identified as a contributory influence; and the continuing "pauperizing" nature of public vaccination provided under the auspices of the Poor Law Board. ${ }^{34}$ It is the main contention of this paper that periods of epidemic smallpox, severe in the metropolis compared to the rest of the nation, were not only caused by the factors outlined above, but were also mediated through the uniquely inadequate operational administration of the vaccination laws in London. It has already been pointed out that, unlike many other public health responsibilities, vaccination fell outside the jurisdiction of the vestries and district boards. The Vaccination Acts of the early 1840 s originally entrusted the service to the Poor Law Guardians, since they "were

example, London's population at risk in 1855 is the mean of the London populations given in the 1851 and 1861 censuses. The figures for London's share of national smallpox deaths for the period 1854-1905 are given in A Hardy, 'Smallpox in London: factors in the decline of the disease in the nineteenth century', Med. Hist., 1983, 27: 111-38, p. 121.

29 Vaccination Act 1853 (16 \& 17 Vict. c. 100).

30 The epidemic in England actually began towards the end of 1870 and lasted until the early months of 1873 . In London, the deaths were heavily concentrated in $1871(7,982$ deaths) rather than 1872 ( 1,747 deaths).

31 The population at risk for the $1-4$ year olds in Figure 2 is calculated in exactly the same way as described in note 28 above. However, two points of clarification should be made. First, the age structure in single year age groups for the under-fives was not given in the 1851 census. For the years $1851-60$, then, the 1861 structure was used for the population at risk in these ages. Second, the number of live births in an individual year was used as the population at risk for infants.

32 Williams draws attention to the likelihood that high rates of population turnover in other British cities contributed to their high levels of smallpox mortality during the epidemic of 1871-72, in Williams, op. cit., note 3 above, pp. 406-8. A similar point has been made for Stockholm in the 1850s and 1860 s in M C Nelson and J Rogers, 'The right to die? Anti-vaccination activity and the 1874 smallpox epidemic in Stockholm', Soc. Hist. Med., 1992, 5: 369-88, p. 378.

${ }^{33} \mathrm{~S}$ F Murphy, 'The causes of the present diffusion of smallpox, and the means which should be adopted for its prevention', Sanit. Rec., 15 March 1881, NS 2: 346.

34 Editorial, 'Vaccination and smallpox mortality', Sanit. Rec., 28 June 1878, 8: 404-6. See also Williams, op. cit., note 3 above, pp. 397-9. 


\section{Graham Mooney}

the only uniform central and local authorities existing on a national scale". ${ }^{35}$ Because the Guardians acted under the supervision of the centralized Poor Law Commission, the role of vaccination in centralization debates has tended to be overlooked. While strong local ideological opposition to compulsory vaccination may have retarded its uptake in some parts of the country, ${ }^{36}$ this provides only a partial picture in London's case, where the ineffectual management of unwieldy and constrictive legislation was a rather more significant factor than elsewhere.

After the introduction of compulsory smallpox vaccination in 1853 , and especially following the tightening up of this legislation in 1867, infant vaccination rates (IVRs) for London, compared to other counties in England and Wales, were consistently below average, never rising above 500 per 1,000 live births for the whole period 1845-90; in the periods $1868-72$ and 1873-81, London's IVRs were actually the lowest in the country. ${ }^{37}$ In 1882-90, Leicestershire - a notable area of opposition to vaccination-was the only county with a rate below that of London. ${ }^{38} \mathrm{~A}$ range of technical reasons may account for London's apparently low uptake. First, the calculation of the IVR is based on the number of registered births. In the view of one experienced commentator, the system of recording these, or at least the ability of the system to detect the registration of a false address, remained defective. ${ }^{39}$ Second, the vaccination registers, which by law the public vaccinators were supposed to keep, were often incomplete, or not even kept at all. Third, a number of infants would have died before the three month time limit imposed by the Vaccination Acts. Underestimation of vaccination rates therefore arises since these deceased infants would be included in the denominator (i.e. births) but not the numerator. It is probable that these particular considerations applied equally across the country, but do not affect the rates enough to preclude the county-level spatial comparisons that have been presented by Williams. ${ }^{40}$ Yet three further caveats have particular relevance for certain districts in London. Some children born in one Poor Law union (of which there were 39 at this time) may well have had their vaccination registered in another. In addition, the constant migration of families with children meant that a great number of both births and public vaccinations of children living in the capital were missing from the respective registers anyway. Finally, the rates are for public vaccinations and do not include operations performed privately.

Fundamental problems at the root of London's vaccination administration facilitated

\footnotetext{
35 An Act to Extend the Practice of Vaccination 1840 (3 \& 4 Vict. c. 29); An Act to Amend an Act to Extend the Practice of Vaccination 1841 (4 \& 5 Vict. c. 32). Hodgkinson, op. cit., note 4 above, p. 28 ; $M$ W Flinn, 'Medical services under the New Poor Law', in D Fraser (ed.), The New Poor Law in the nineteenth century, London, Macmillan, 1976, pp. 45-66, on pp. 51-2.

${ }^{36}$ MacLeod, op. cit., note 4 above, and D Porter and R Porter, 'The politics of prevention: antivaccinationism and public health in nineteenthcentury England', Med. Hist., 1988, 32: 231-52; A Beck, 'Issues in the anti-vaccination movement in England', Med. Hist., 1960, 4: 310-21.
}

\footnotetext{
37 Williams, op. cit., note 3 above, pp. 401-3.

38 S M F Fraser, 'Leicester and smallpox: the Leicester method', Med. Hist., 1980, 24: 315-32.

${ }^{39}$ In 1882, Henry Stevens-one of Simon's team of medical inspectors at the Privy Councilsuggested that despite the penalties introduced under the 1874 Registration Act, there was "a very large class of people, and I am afraid a very increasing class . . . who do not have the births of their children registered, or who register with false addresses on purpose to avoid vaccination", Royal Commission on Smallpox and Fever Hospitals, Parliamentary Papers (henceforth PP) 1882, xxix, p. 197.

40 Williams, op. cit., note 3 above, p. 402.
} 


\section{Smallpox Vaccination in Nineteenth-Century London}

these loopholes. The 1858 Public Health Act gave power to the Medical Department of the Privy Council to supervise vaccination services. ${ }^{41}$ Royston Lambert has recounted how John Simon assembled an impressive team of young, highly qualified and motivated assistants, appointed on a temporary basis, to fulfil the Department's task of inspecting, reporting and advising on local public health matters. ${ }^{42}$ As part of Simon's programme to restructure the service, by 1864 four members of this team-Henry Stevens, John Burdon Sanderson, George Buchanan, and Edward Seaton-had amassed a mountain of information regarding vaccination practice in England and Wales. Seaton and Buchanan were responsible for the detailed investigation of London's vaccination apparatus during $1861-62.43$ As in all other localities across the nation, the operation of public vaccination in London depended upon a triangular framework of responsibility involving the local Boards of Guardians, the public vaccinators and parents. Seaton and Buchanan suggested that the uniquely inadequate functioning of this triumvirate in London was the main cause of the capital's low vaccination rates, and the following paragraphs detail the inspectors' claims. $^{44}$

\section{Boards of Guardians}

Under the provisions of vaccination legislation, the duties of the Guardians were threefold. First, they were obliged to appoint both the public vaccinators and their stations and set the regulations pertaining to the attendance of the vaccinators; second, they were supposed to issue public notifications of vaccination; and finally they were empowered to institute proceedings for the enforcement of vaccination. Obviously, then, the local Guardians had strong, independent control over the arrangements for public vaccination.

The mere association of vaccination with the pauper authorities was a severe handicap to the system; it was often logical for the Guardians to appoint the Poor Law Medical Officer (PLMO) as the public vaccinator. Only five of the London unions-St George Hanover Square, Paddington, St James Westminster, Hampstead and Clerkenwell-made vaccination arrangements separate from the Poor Law medical structure. Many other parishes had a combination of the PLMO and other, independent, practitioners acting as

${ }^{41}$ Public Health Act 1858 (17 \& 18 Vict. c. 95$)$.

${ }^{42}$ R J Lambert, Sir John Simon, 1816-1904: and English social administration, London, MacGibbon and Kee, 1963, pp. 312-17.

${ }^{43}$ Edward Cator Seaton was a leading authority on vaccination and worked closely with Simon. He was secretary of the Epidemiological Society's Vaccination Committee and succeeded Simon as Medical Officer of the Local Government Board in 1876. George Buchanan was the MOH for St Giles district in London and had been physician at the London Fever and Sick Children's Hospitals.

Buchanan replaced Seaton as Medical Officer at the LGB after the latter's retirement and death in 1879. Ibid., pp. 252-3, pp. 317 and 574.

${ }^{44} \mathrm{E} C$ Seaton and G Buchanan, 'Report on the state of public vaccination in London, and on the recent epidemic of smallpox', Report of the Medical Officer of the Privy Council, 1863 (henceforth RMOPC), PP 1864, xxviii, Appendix 1. This report is also discussed in Hardy, op. cit., note 5 above, pp. 116-28. The peripatetic inspectors' other county-bycounty reports are similar in conception, structure and content to that for London. Seaton later noted "that the districts into which the Kingdom is divided for the purpose of public vaccination exhibit every shade of variety as to the extent to which vaccination is carried out,- - from complete observance of the law, to the most culpable and reckless disregard for it". He was particularly scathing of vaccination administration in all large cities. E C Seaton, $A$ handbook of vaccination, London, Macmillan, 1868, pp. 257 and 367. 


\section{Graham Mooney}

public vaccinators. Yet in nearly half of the 39 London parishes it was the PLMO alone who held the contract. ${ }^{45}$ Public vaccination was not merely an additional consideration to other aspects of pauper medical relief, but was often a subjugated duty. In the opinion of the inspectors, the vaccinators' remuneration was too low. Despite this, the rate of payment in some unions was actually higher than the PLMO received for the performance of other medical services. In consequence, local Guardians exploited this to underpay medical officers for their non-vaccinating duties. ${ }^{46}$

\section{Table 1}

Public vaccinators' contractual arrangements in London Poor Law unions, 1861-62

Number of vaccinators Attendance frequency Number of stations covered

$\begin{array}{lll}20 & \text { no specific arrangements } & \\ 60 & 1 \text { per week } & 73 \\ 58 & 2 \text { per week } & 63 \\ 10 & 3 \text { per week } & 10 \\ 84 & \text { daily } & 93\end{array}$

Source: RMOPC, 1863, p. 95.

It was also incumbent upon the Guardians to ensure that the vaccinators adhered to the terms of their contract, which the Guardians themselves were responsible for drawing up. As one might expect, the terms of the contracts varied widely across the capital, and Table 1 details the official contractual arrangements. Although 20 of the vaccinators had no specific agreement with the Guardians, coverage over the whole of London should have been reasonably comprehensive. Closer examination generally confirmed this, but the vaccinators commonly veered from the agreed terms. Seventy-seven vaccinators (33 per cent) attended on one week day; 44 twice per week (19 per cent); the remaining 111 attended either several days or every day of the week ( 48 per cent) ${ }^{47}$ Laxity in monitoring the contracts seems to have been generally symptomatic of the Boards' attitude to their vaccination responsibilities.

Notification of the arrangements was required to be published by the Guardians. Yet it was only during epidemic periods that this particular rule was observed, and the practice of informing the public was not universal. The notices were often not comprehensive and were frequently superseded by new arrangements, thus conflicting with the instructions given to parents by the registrar of births. In non-epidemic times, only 16 of the 39 parishes managed to notify the public and 8 of the 16 provided simple placards issued on an irregular basis (perhaps every one or two years). Nevertheless, such arrangements as billed were frequently overridden by new ones, or the vaccinators made new arrangements themselves and these were not always publicized. Some placards merely informed parents of the vaccination laws, but neglected to give information appertaining to the vaccination

${ }^{45}$ RMOPC, 1863 , op. cit., note 44 above, p. 93. There were 232 vaccinators in London, attending a total of 260 stations.
46 Ibid., p. 93.

${ }^{47}$ Ibid., p. 95. 


\section{Smallpox Vaccination in Nineteenth-Century London}

arrangements in that district. Certainly there was ample scope for confusion. In St Luke Chelsea, one contractor's schedule arranged for attendance on Tuesdays and Fridays between 9 and 10 o'clock; yet the placard issued by the Guardians announced that he would attend daily at 9 am; the registrar of births and deaths advertised that he attended on Thursday at half past nine; while the inspectors found he vaccinated chiefly on Mondays and also in his private surgery every morning from 9 to $10 !^{48}$

In view of such farcical arrangements-and St Luke's does not appear to have been unique - it seems ironic that it should fall to the Guardians to appoint an officer with the remit of prosecuting defaulting parents. ${ }^{49}$ In view of their overall unwillingness and inability to provide an efficient service, it is perhaps not surprising that the Guardians in only 10 of the 39 unions had elected to do this by 1863 , especially since such prosecutions were not funded from the rates. The prosecuting officer, when appointed, generally came from a variety of "public service" backgrounds, the officership being additional to their existing duties. Either the assistant Poor Law overseer or the relieving officer, the sanitary inspector, the $\mathrm{MOH}$, the registrar, or the public vaccinator himself, served in this capacity. Only nine London unions had served warnings to defaulters on a regular basis and this was normally found to be sufficient action. Where proceedings had been instigated, the case collapsed in four unions due to the absence of a registered birth. Of all the authorities, only Paddington and Poplar had pursued prosecutions to the point of imposing a fine. Whilst agreeing in principle, in practice the Guardians were reluctant to prosecute under any circumstances in order to avoid creating an atmosphere of ill-will amongst the local population and, perhaps more significantly, their ratepaying electors. ${ }^{50}$

\section{Public Vaccinators}

The vaccinators' contractual regulations required them to attend for vaccination at appointed times in person or by legal deputies; perform vaccination according to the instructions; inspect the results of these vaccinations; keep a register; and give certificates to parents and registrars verifying successful vaccination. ${ }^{51}$ Although the vaccinators were theoretically under the scrutiny of the Guardians, Seaton and Buchanan alleged that gross imperfections were to be found in the practice of all these duties. The majority of the vaccinators employed in London (132 of 232) performed the vaccinations themselves. Under Clause Two of the 1858 Public Health Act, the Privy Council had supposedly ensured that the Guardians could not contract vaccination out to any person entering the medical profession after 1860 and not possessing the Council certificate of proficiency. Nevertheless, none of the credentials of the 90 deputy vaccinators-largely employed throughout the capital to conduct house-to-house visits to ascertain the success of vaccinations - had been scrutinized by the local Guardians. In the event, whilst 36 had the legal requirements and a further 18 possessed "some medical diploma", another 36 were

${ }^{48}$ Ibid., pp. 98-9.

${ }^{49}$ An Act to Facilitate Proceedings Before the Justices Under the Acts Relating to Vaccination 1861 (24 \& 25 Vict. c. 59). However, it should be noted that the appointment of these officers was not compulsory until the Vaccination Act 1871 (34 \& 35 Vict. c. 98).
${ }^{50} R M O P C, 1863$, op. cit., note 44 above, p. 99. The inspectors were of the general impression that "[w]hile many of them [Guardians] would not have demurred to such proceedings in the abstract, they considered that these measures ought to be taken by a public prosecutor, independent of local ties".

51 Ibid. 


\section{Graham Mooney}

without any medical qualification at all. Those deputies in possession of the medical qualifications were normally partners in the practice and often performed a large share of the vaccinations, but in twelve instances, unqualified deputies performed a considerable majority of the operations. 52

As noted, a number of the deputies were involved in the inspection of the results of vaccination and this was reasonably well carried out. Most of the children were returned to the vaccinating station for inspection one week after the performance of the operation. Yet the general consensus of the vaccinators was that the quality of between one-quarter and two-thirds of all vaccinated cases remained unconfirmed. In some cases, the mere hearsay of the parents or neighbours was considered to be sufficient verification, whilst some vaccinators assumed success if the child was not brought back. A number of these unsuccessful cases were not even entered in the vaccination registers, and in only 6 of the 205 registers the inspectors examined were the records considered to be of satisfactory quality. ${ }^{53}$ The Guardians themselves rarely scrutinized the quality of the registers in detail, although abstracts were frequently presented at weekly or fortnightly Board meetings. This is an especially important point. First, since the registers determined payment of the account, imperfect registers resulted in inaccurate payments. Second, the information contained in the registers was compiled for the annual returns to the Poor Law Board, upon which contemporary opinion about the extent and quality of vaccination was based. Yet the inspectors "found in nearly half the unions errors of some magnitude, and that the return was in some cases altogether unreliable".54

The vaccinators were required to provide parents with a certificate of successful vaccination and over 70 per cent of the 191 vaccinators in London who were asked asserted that they performed this duty in all cases. The remainder issued the certificates either irregularly or not at all. Far more problematic was the sending of a duplicate certificate to the registrar, who was supposed to keep a record of the successful vaccinations. Although 189 of the vaccinators alleged that they did so, Seaton and Buchanan suggested, "it is certain that some of these must have spoken rather of a recently adopted or of an intended practice than of a habit steadily pursued, as the statements were not always reconcilable with the entries in the books of the registrars". 55 Indeed, it was discovered that only ten registrars had recorded the vaccination of over 50 per cent of the births in their sub-district. The system of duplicate certificates was doubtless cumbersome, but in at least six unions the Guardians required evidence of the delivery of the certificate in order to ensure payment for the vaccination.

\section{Parents}

The steps parents took for having (or refusing to have) their newly born infant vaccinated were conditioned not only by the legislation, but also by socio-cultural beliefs

\footnotetext{
52 Ibid., p. 100. Stepney and Mile End Old Town were the two primary offenders in this case.

${ }^{53}$ Ibid., p. 103. Thirty-six per cent did not list unsuccessful vaccinations; re-vaccinations were not always defined separately from primary ones; and the source of lymph was listed in only 10 of the 205; and dates were frequently omitted or only irregularly
} 


\section{Smallpox Vaccination in Nineteenth-Century London}

and the fear that vaccination would transmit other diseases, such as syphilis. ${ }^{56}$ However, Seaton and Buchanan's report demonstrates that the interpretation placed upon the law by the Guardians and the public vaccinators, and the efficiency and manner in which they fulfilled their duties, was also a conditioning factor. Parents could hardly have been held negligent for failing to have their child vaccinated if the times of vaccination were notified wrongly or not at all; or if these times conflicted with those given by the Registrar of births; or if the vaccinator was simply not present at the notified time; or if there was no lymph available. Yet there is certainly evidence of what was termed "domestic neglect" during the Privy Council investigations of the early 1860s. Medical assistance was often not sought until the disease had taken hold, and unvaccinated children were found to be living close to infected houses, if not in an infected house itself. It was probable that smallpox cases were often concealed, but the possibility of vaccination avoidance upon ideological grounds was summarily dismissed:

Objection to vaccination on the part of parents was indeed often alleged to exist; but "objection" appeared to be usually another word for an excuse to account for the parents' neglect. And when such objection really was entertained it generally related to the early age at which vaccination was required (the grounds for early vaccination being very ill understood), or it was prompted by a fear of eruptions following vaccination, and by a vague want of confidence in the lymph employed, and in the way of performing the operation by the local vaccinators. Real repugnance to vaccination altogether, although doubtless existing in the minds of some few persons, did not appear to be the hindrance in any appreciable number of those instances where vaccination was neglected. ${ }^{57}$

This, however, flies in the face of the evidence which followed the 1871 Vaccination Act, whereby the Guardians were obliged to appoint a paid vaccination officer, and prosecute persons who failed to comply with the legislation. This legislation provided the focus for the emergence of a co-ordinated anti-vaccination movement and the pages of the Sanitary Record, for example, are liberally sprinkled with reports of prosecution cases across the country. ${ }^{58}$ In one instance, a dairyman from Notting Hill, Mr Frederick Keen, had reportedly "followed and threw the [vaccination] notice" for his six children at the officer. Appearing in court alone because three of his children were at home minding the family business, he argued that, "the children were his property and not the property of the state". ${ }^{59}$ Opposition to vaccination need not have been as publicly demonstrative as this example suggests. If, as Stevens had implied in his evidence to the Royal Commission in 1882 , it was simple to give a false address at birth registration, then this would have been one way in which parents could satisfy their ideological disapproval of vaccination. ${ }^{60}$ Moving from one Poor Law union to another before the three months allowed for vaccination had elapsed would have been another method for parents to register a silent protest. None the less, the combined ranks of the public health professionals-generally for whom nothing was "more clear than that no person is at liberty, under any plea whatever, to be a source of danger to the health and lives of others, and this the

\footnotetext{
${ }^{56}$ MacLeod, op. cit., note 4 above; Beck, and Porter and Porter, op. cit., note 36 above.

${ }^{57} R M O P C, 1863$, op. cit., note 44 above, pp. $104-5$.

${ }^{58}$ Between 1879 and 1890 in England and Wales, the number fined for non-compliance with the acts
}

was 10,660, whilst 113 had been imprisoned. Return of convictions under Vaccination Acts 1889-90, PP 1890, lix, pp. 595-621.

59 Anon., 'Non-vaccination', Sanit. Rec., 18

December 1875, 3: 440 .

${ }^{60}$ Stevens, op. cit., note 39 above. 


\section{Graham Mooney}

unvaccinated person unquestionably is" 61 - were convinced of the efficacy of vaccination, and in order to avoid legitimizing the claims of the anti-vaccination lobby, were more likely to blame apathy and indifference on the part of parents rather than objections on ideological grounds. ${ }^{62}$ There is little reason to believe, however, that ideological disapproval was not the cause of at least part of the non-vaccination before 1871.

\section{The Location of Vaccination Stations}

Rather than any ground-swell of abstinence caused by collective ideological censure of state interference with individual liberty, in the view of Seaton and Buchanan the amount and effectiveness of vaccination in the capital were primarily determined by flaws in the administrative structure. The convergence of these flaws is best exemplified by a discussion of the geographical location of the vaccination stations. Adequate provision of accessible stations was vital for both quantity and quality of vaccination. Responsibility for the designation of the stations ultimately lay with the Board of Guardians and thus the association of public vaccination with parochial relief became a matter of premises as well as personnel. In St Giles, for example, the workhouse was sometimes used as the vaccination station. In other unions parish property was used, as in St Olave where the vestry-room doubled up as the vaccination station. It was not uncommon for the Guardians to disregard their obligation and allow the vaccinator to select a station of his own choosing, and the association of the PLMO with the workhouse meant that the place and time of vaccination was often identical to the PLMO's attendance upon sick paupers there. So feared was the stigma of association with pauperization, that "in St George East many parents refused to let their children be touched by the public vaccinator himself, who was the workhouse surgeon, but made no difficulty in applying at the surgery of his deputy, who had no parochial appointment". ${ }^{63}$ For those parents willing to have their newly-born infant vaccinated, even getting to a station could prove frustrating. They were often required to travel a considerable distance to a station belonging to their union, even though that of a neighbouring union was much closer to their home. A variety of examples of the inconvenience caused by these arrangements were cited by the inspectors. The station for the parish of St Giles and Bloomsbury was half a mile from the poorer parts of the Bloomsbury parish, whereas two stations in St Pancras parish were both within "ten doors" of the Bloomsbury boundary. ${ }^{64}$ Thus, a situation was created where "the station of either vaccinator would have been well supported if it got cases from the entire neighbourhood, [but] it was in fact very badly supplied with children through the division of the local vaccination between it and the station immediately adjacent". ${ }^{65}$ On the other hand, a number of stations within one parish could be almost next door to each other. For example, there were three stations within 100 yards in St Saviour Southwark, and three on Dean Street in Soho. ${ }^{66}$ Obviously, then, the problem was not only that some vaccination stations were awkward to reach, but that parochial sub-divisions prevented attendance at the most convenient station.

${ }^{61}$ Anon., 'Vaccination prosecutions at Mile End Old Town', Sanit. Rec., 18 July 1874, 1: 52.

${ }^{62}$ Hardy, op. cit., note 5 above, pp. 121 and 132.

${ }^{63} R M O P C, 1863$, op. cit., note 44 above, pp. 93-4. Hardy, op. cit., note 5 above, p. 118.
64 Ibid., p. 93. Hardy, op. cit., note 5 above, p. 117.

${ }^{65}$ RMOPC, 1863 , op. cit., note 44 above, p. 93.

66 Ibid., p. 94. 


\section{Smallpox Vaccination in Nineteenth-Century London}

\section{The Quantity and Quality of Vaccination}

Seaton and Buchanan's suggestions for solving this problem and how these relate to the centralization issue will be discussed later. The concern here is the extent to which the location and provision of vaccination stations influenced the quality and quantity of vaccination. The number of stations in a union was not a particularly influential factor in determining the extent of vaccination, despite the fact that London was well provided with them. ${ }^{67}$ Paradoxically, the large number of stations (260) was probably detrimental to the quality of vaccination. Over the two years $1861-62,46,067$ vaccinations were performed in the capital, producing an average attendance of less than one child at each station on each vaccinating day, a problem exacerbated by the practice of vaccinating children in their own homes. The Privy Council recommended an average attendance of at least 10 children per vaccinating day, thus enabling the opportunity to vaccinate directly from the arms of other children. Based upon this, an annual average attendance of 500 for a vaccinating station was considered to be a primary test of the efficient working of that station. Table 2 serves to show that the administrative sub-division of London meant that a very small number of the vaccinators managed to achieve this optimum figure. It was those stations with between 200 and 500 vaccinations per year which managed successfully to maintain arm-to-arm vaccinations. Yet such a record could be kept up only through the particular diligence of the vaccinator, strict adherence to the advertised vaccinating time, and the provision of ample space for the reception of children, which facilitated arm-to-arm vaccination. ${ }^{68}$

Table 2

The average number of vaccinations occurring in London's public vaccination stations, 1861-62

$\begin{array}{cc}\text { Average number of vaccinations } & \text { Number of stations } \\ \text { Over } 500 & 19 \\ 200-499 & 66 \\ 100-199 & 51 \\ 50-99 & 43 \\ \text { Below } 50 & 31\end{array}$

Source: RMOPC, 1863 , p. 96

Such arrangements could not fail to have had a detrimental affect on the level of vaccination in London. Seaton later summed it all up rather well:

The intention which underlay these arrangements for frequent attendances was most laudable. It was evidently that of making vaccination as easily attainable to the public as possible. And if vaccination could be properly administered, as physic is poured out of a bottle, to any comer at any time, there

${ }^{67} \mathrm{G}$ Mooney, 'The geography of mortality decline in Victorian London', $\mathrm{PhD}$ thesis, University of Liverpool, 1994, p. 196.

68 Sometimes a recently vaccinated child was sent for to provide fresh lymph. In the opinion of the inspectors this situation, although providing for armto-arm vaccination, was to be discouraged on two counts. First, it may still have resulted in the use of lymph from second-rate scars, the alternative being preserved lymph. Second, it was argued that the fetching of the child and the maintenance of the armto-arm method at any event tended to lower both the station and the operation itself in the eyes of the public, "who come to regard the vaccination of their children as a private favour done to the vaccinator". RMOPC, 1863, op. cit., note 44 above, p. 97. 


\section{Graham Mooney}

Table 3

Public infant vaccination rates per 1,000 live births in London registration districts, $1860-62$ and $1862-63$

\begin{tabular}{|c|c|c|c|c|c|}
\hline District & $1860-62^{1}$ & $1862-63^{2}$ & District & $1860-62$ & $1862-6$ \\
\hline West London & & & East London & & \\
\hline Paddington & 319 & 408 & Shoreditch & 411 & 602 \\
\hline Kensington & 272 & 451 & Bethnal Green & 430 & 543 \\
\hline Fulham & 402 & 568 & Whitechapel & 641 & 680 \\
\hline Chelsea & 456 & 623 & St George-in-the-East & 397 & 608 \\
\hline St George Hanover Sq & 396 & 351 & Stepney & 452 & 593 \\
\hline Westminster ${ }^{3}$ & 609 & 831 & Mile End Old Town & 386 & 444 \\
\hline Marylebone & 455 & 491 & Poplar & 444 & 671 \\
\hline North London & & & South London & & \\
\hline Hampstead & 221 & 195 & St Saviour Southwark ${ }^{7}$ & 392 & 488 \\
\hline Pancras & 393 & 462 & St Olave Southwark ${ }^{8}$ & 378 & 469 \\
\hline Islington & 371 & 523 & Lambeth & 374 & 459 \\
\hline \multirow[t]{2}{*}{ Hackney } & 497 & 354 & Wandsworth & 301 & 492 \\
\hline & & & Camberwell & 399 & 600 \\
\hline Central London & & & Greenwich & 473 & 584 \\
\hline St Giles & 249 & 270 & Lewisham ${ }^{9}$ & 388 & 420 \\
\hline Strand ${ }^{4}$ & 479 & 539 & & & \\
\hline Holborn $^{5}$ & 400 & 486 & & & \\
\hline London City ${ }^{6}$ & 389 & 451 & London total & 417 & 517 \\
\hline
\end{tabular}

Source: RMOPC, 1863, p. 121.

Notes:

${ }^{1}$ mean of years $1860-61$ and $1861-62$.

2 year $1862-63$.

3 includes St James Westminster.

${ }^{4}$ includes St Martin-in-the-Fields.

5 includes Holborn, Clerkenwell and St Luke.

6 includes London City, West London and East London.

${ }^{7}$ includes St Saviour Southwark, St George Southwark, and Newington.

8 includes St Olave, Bermondsey and Rotherhithe.

${ }^{9}$ includes Woolwich.

would have been nothing objectionable in them. But, in fact, they had been conceived without any reference to the essential nature of the thing that had to be done. ${ }^{69}$

In 1854-56, Simon's analysis had shown that the percentage of births publicly vaccinated in London parishes could range from 28 to 81 per cent. He presumed that "corresponding differences of merit in the local arrangements for public vaccination" accounted for this pattern. ${ }^{70}$ Little had changed by the early 1860 s, and with few exceptions across London a high proportion of the infant population entering their second

${ }^{69}$ Seaton, op. cit., note 44 above, pp. $365-6$.

$70 \mathrm{~J}$ Simon, Papers relating to the history and practice of vaccination, London, HMSO, 1857, $\mathrm{p}$. lxxii. 


\section{Smallpox Vaccination in Nineteenth-Century London}

year were probably unvaccinated. As Table 3 shows, even during the 1862-63 epidemic period, when both the authorities and parents would have generally been more vigilant, public IVRs were as low as 195 per 1,000 live births in Hampstead and 270 per 1,000 in St Giles. ${ }^{71}$ Thus far in this paper, the distinction between public and private vaccination has been carefully preserved. It is a complicated task to comment upon the prevalence of the latter before the 1870 s, since the published information does not directly record the number of operations being performed by family doctors. The statistics yielded by the implementation of the 1871 Vaccination Act do, however, shed some light on the issue. The local Vaccination Officer (VO) compulsorily appointed under this legislation (see note 49 above) received a monthly list of births from the local registrar. Every birth could then be matched up with a corresponding certificate of vaccination authorized by either a public vaccinator or a private practitioner. ${ }^{72}$ The VO was responsible for sending in the annual total of certified public and private vaccinations of the district to the LGB's Medical Department for tabulation and analysis. By subtracting the annual number of public infant vaccinations (data which appears in the annual Reports of the LGB) from this total, it becomes possible to gauge the regional public/private split of vaccination operations. ${ }^{73}$ The results of this procedure are shown in Table 4, where public and private IVRs for England and Wales and London between 1872 and 1890 are given, the former

\section{Table 4}

Estimated public and private infant vaccination rates per 1,000 live births, London and England and Wales, 1872-90

\begin{tabular}{lcccc} 
& & London & \multicolumn{2}{c}{ England and Wales } \\
& Public & Private & Public & Private \\
1872 & 363 & 457 & 571 & 279 \\
1875 & 384 & 426 & 557 & 292 \\
1880 & 413 & 425 & 556 & 295 \\
1885 & 422 & 413 & 544 & 303 \\
1890 & 366 & 389 & 467 & 313
\end{tabular}

Sources: $A R L G B$ and $R M O L G B$ in the relevant years.

Note: See note 73 in the main text for the method used to calculate these rates.

${ }^{71}$ Acting upon orders from the Privy Council, the local authorities were at pains to step up their activities during the epidemic. All the unions bar three issued special placards regarding vaccination arrangements, temporary vaccinating officers were employed and twelve unions ordered either periodical reports or set up monitoring committees. Islington and Clerkenwell unions paid three times the normal rate to ensure the admittance of their smallpox victims to the Highgate Hospital, while most other unions provided special accommodation when the hospital was full. For the vestries and district boards, MOHs conducted special inspections of schools and produced reports on the progress of smallpox in their districts. $R M O P C, 1863$, op. cit., note 44 above, pp. 110-11.

72 If the VO failed to receive a certificate, the subsequent investigation into the circumstances of non-compliance could lead to prosecution, as stipulated in the 1867 Vaccination Act.

${ }_{73}$ Unfortunately, the data on "successful" public infant vaccinations are given only at county level. Further, this data refers to years ending on 29 September. In order to construct Table 4, the chronological mismatch between the public vaccinations and the total vaccinations was corrected 


\section{Graham Mooney}

being the first date for which the total number of infant vaccinations is available. ${ }^{74}$ It appears that almost one third of all infant vaccinations in England and Wales were performed privately. In London, although the level of public vaccination gradually increased as the 1871 Act took hold, the proportion of private vaccinations was much higher, consistently accounting for about 400 infant vaccinations per 1,000 live births. Why this should be the case is unclear. Certainly, the evidence provided in this paper suggests that Londoners' perception and usage of the public vaccination system would probably have been undermined by the inadequate working of it by the authorities. Further, it was known that many wealthy parents preferred to pay for a private vaccination rather than avail their children of the gratuitous facilities on offer at the public stations. ${ }^{75}$ It may well be that the concentration of such families in certain parts of London served not only to lower the percentage of public infant vaccinations in these districts, but was also significant enough to reduce the level in the metropolis overall. Whether these assumptions apply to the time before the 1867 and 1871 Vaccination Acts must remain a moot point-certainly the public IVRs presented earlier in Table 3 should take into account the possibly weighty contribution made by private vaccinations to the prevention of smallpox in some London districts.

The issue of vaccination quantity becomes almost inconsequential should that vaccination be performed improperly on a wide scale. An evaluation of quality cannot be conducted without reference to the method of the operation itself, especially since vaccination does not confer life-long immunity. There were a number of methods of inserting lymph into the arm, but puncture was the mode recommended by the Privy Council. Four or five separate punctures were the optimum in order to produce four or five vesicles, which by the eighth day should have had a distended appearance containing clear lymph. ${ }^{76}$ The success of the operation also depended upon the quality of the lymph available. In this period, it was believed that the best lymph was obtained fresh from the arm of a recently vaccinated child around about this eighth day. ${ }^{77}$ Inspection of the results in the station also afforded the opportunity to perform arm-to-arm vaccinations on unvaccinated children. In the absence of recently vaccinated children, however, vaccinators used preserved lymph on ivory points or in capillary tubes, either maintained by themselves or provided by the National Vaccine Establishment in emergencies. Seaton and Buchanan discovered that of the 229 vaccinators they assessed, 157 of them operated by puncture. Twenty-five per cent of the 157 made three marks or less, which was at least one fewer than the number recommended by the Privy Council. It appeared that the vesicles "were for the most part of an extremely superficial character, not producing with

by assuming that the percentage of births publicly vaccinated in any given year ending 29 September applied to the calendar year. All the caveats outlined earlier in the paper concerning the accuracy of the public vaccinators' registers should be borne in mind when assessing these figures.

${ }^{74}$ Not until 1873 were revaccinations and primary vaccinations separated in the published tables. However, the overwhelming majority of infant vaccinations, if not all of them, were primary, so this should not unduly affect the figures.

${ }^{75} \mathrm{G}$ Buchanan, Supplement to the 11th annual report of the Local Government Board, containing the report of the Medical Officer, 1881 (henceforth $R M O L G B$ ), PP 1882, xxx part 2, p. vii.

${ }^{76}$ Order of Council, 'Signs of successful vaccination and of successful revaccination (Gregory, revised by Ceely and Marson)', RMOPC, 1859, PP 1860, xxix, pp. 214-15.

${ }^{77}$ The danger of secondary infection from arm-toarm vaccination was only recognized by legislation in 1898 , when it was prohibited and glycinerated calf-lymph was used. 


\section{Smallpox Vaccination in Nineteenth-Century London}

constancy, even when fresh lymph was used, the 'good sized vesicles' which the instructions require". ${ }^{78}$ Seventy-two vaccinators operated by abrasion, scratch or superficial cuts. A total of 44 of this group produced less than three spots on the arm by this method, although in some cases this was adequate to produce the desired result.

To further assess vaccination quality Seaton and Buchanan examined the vaccination marks on the arms of almost 50,000 children in a collection of schools, industrial establishments and workhouses across London. Only 8,901 children in the sample (18 per cent) were vaccinated to the standard of four well-sized marks (cicatrices) as directed by the Privy Council and just over one third of the vaccinated children $(17,597)$ had three "good" scars. It is very difficult to be confident about discussing spatial differences in the quality of vaccination because a greater proportion of children examined in some districts came from the "ragged" and industrial schools where more unvaccinated children were to be found. ${ }^{79}$ Nevertheless, the extensive inquiry concluded that the overall quality of public vaccination across the whole of London in the early 1860 s was poor.

Once again, the official records of this period are comparatively silent about the efficiency of private vaccinators. An investigation by Henry Stevens of the vaccination history of each of the 2,379 smallpox deaths in London in 1881, however, makes it appear highly unlikely that private vaccination was in any way superior to that provided publicly. Of the 125 smallpox deaths to allegedly vaccinated children under 10 years of age, only 35 were publicly vaccinated as opposed to 82 privately (after detailed inquiry, it was discovered that the remaining eight children had not in fact been vaccinated). ${ }^{80}$ Although he was prepared to concede that some private vaccination was undoubtedly of the standard required, George Buchanan maintained that these results underlined the inadequacy of much private vaccination, the superficiality of which was actually adopted as a sellingpoint by its exponents:

It . . . offers itself in competition with public vaccination, and parades its inefficiency as a reason for its acceptance by ignorant people. Its professors say to young mothers, "Do you come to me, and I won't hurt your baby; I'll make only one place on its arm, not four, as those public vaccinators do". 81

The following section demonstrates that although the problem of securing efficient public and private vaccination provided a convincing case for the centralization of London's sanitary administration, the link of public vaccination with the Poor Law, together with the political leverage wielded by the vestries and district boards, ensured that the argument remained ineffectual.

${ }^{78}$ RMOPC, 1863 , op. cit., note 44 above, p. 100. They were of the opinion, "that fully half of those who operated by puncture were satisfied with an amount of local effect inadequate for satisfactory protection".

${ }^{79}$ Some schools required vaccination as a condition of entry, although the inspectors found that in practice the difference between these and other schools in terms of the proportion of children vaccinated was minimal.

${ }^{80} \mathrm{H}$ Stevens, 'Memorandum on smallpox in London in 1881 , with special reference to its relation to public vaccination', $R M O L G B, 1881$, op. cit., note
75 above, Appendix 8, pp. 45-56, Table E on p. 52. Of the $\mathbf{3 5}$ deaths to publicly vaccinated children under 10 years of age, Stevens revealed that 12 were vaccinated whilst incubating the disease and of the other 23 he reckoned that only one had been vaccinated to the standard required by the LGB.

${ }^{81}$ In Buchanan's opinion, Stevens' findings intensified the argument against private vaccination, since it was the offspring of the upper classes that constituted the bulk of privately vaccinated children, yet they were less likely to be exposed to smallpox infection than poor children, op. cit., note 75 above. 


\section{Graham Mooney}

\section{A Central Vaccination Authority for London?}

It stands to reason, to anyone who knows anything about the metropolis, that what we want is unification. The Guardians are very touchy bodies, and I doubt whether they would not resist very much indeed having this [vaccinating] duty taken out of their hands, although they do not all do their duty. ${ }^{82}$

The outstanding feature of the inquiry conducted by Seaton and Buchanan was its emphasis upon the ineptitude and unwillingness of the local Poor Law Guardians to fulfil their obligations regarding vaccination legislation. In order to rectify what was seen as an appalling situation, the recommendations of the inspectors centred around two objectives: first, to secure the uniform performance of arm vaccination with selected lymph for children publicly vaccinated in London; second, to extend to the ordinary public vaccination stations the supervision provided for in the organization of the National Vaccine Establishment. ${ }^{83}$ But what exactly did this entail? The two inspectors outlined what they felt would be an ideal set of conditions. Vaccination should be at stated times, taken direct from the arms of other children with the best type of lymph. The operation should be performed by the appointed vaccinator, or a legal deputy. Successful vaccination should be ensured by proper inspection, and adequate accommodation be provided for the patients. Finally, the stations should be within a reasonable distance for parents to take their children. Although they simply appeared to be condoning the standardization across London of what they considered the best vaccinating practices, it was argued that some of these conditions could be met only through a radical rationalization in the number of vaccination stations across the metropolis. In excess of the Privy Council's recommendations, it was suggested that the best form of arm vaccination could only be fully performed with an average of one thousand annual cases. Two such stations operated successfully in Manchester and Birmingham, and it was estimated that in the latter there was only one unsuccessful operation in a total of 1,205 during $1863 .{ }^{84}$ This plan involved the maintenance of about fifty or sixty stations in London. If these stations were located as shown in Figure 3, the inspectors argued that, on average, no house would be more than a quarter of a mile from a station.

With this apparently common-sense plan, based upon the concept that parents had the right of free access to a nearby vaccination station of their choosing, the inspectors proposed to abolish the inconvenience that parochial boundaries imposed upon the smooth operation of vaccination in the capital. Because no central authority existed in London for co-ordinating the actions of 39 unions, or to which their responsibilities could be transferred, a committee on the Metropolitan Board of Works or a special Vaccination Board to deal exclusively with metropolitan vaccination was proposed. Such a body would have the following eight duties:

1. The fixing of the vaccination station location, under the conditions outlined above.

2. The appointment of the vaccinators, who would be restricted in number.

3. Assuring the attendance and performance of the vaccinators.

82 Stevens, op. cit., note 39 above, p. 199.

${ }^{83}$ RMOPC, 1863 , op. cit., note 44 above, p. 115.

${ }^{84}$ Ibid., p. 116 . They would also aid private practitioners who could rely on the stations to supply fresh lymph. 


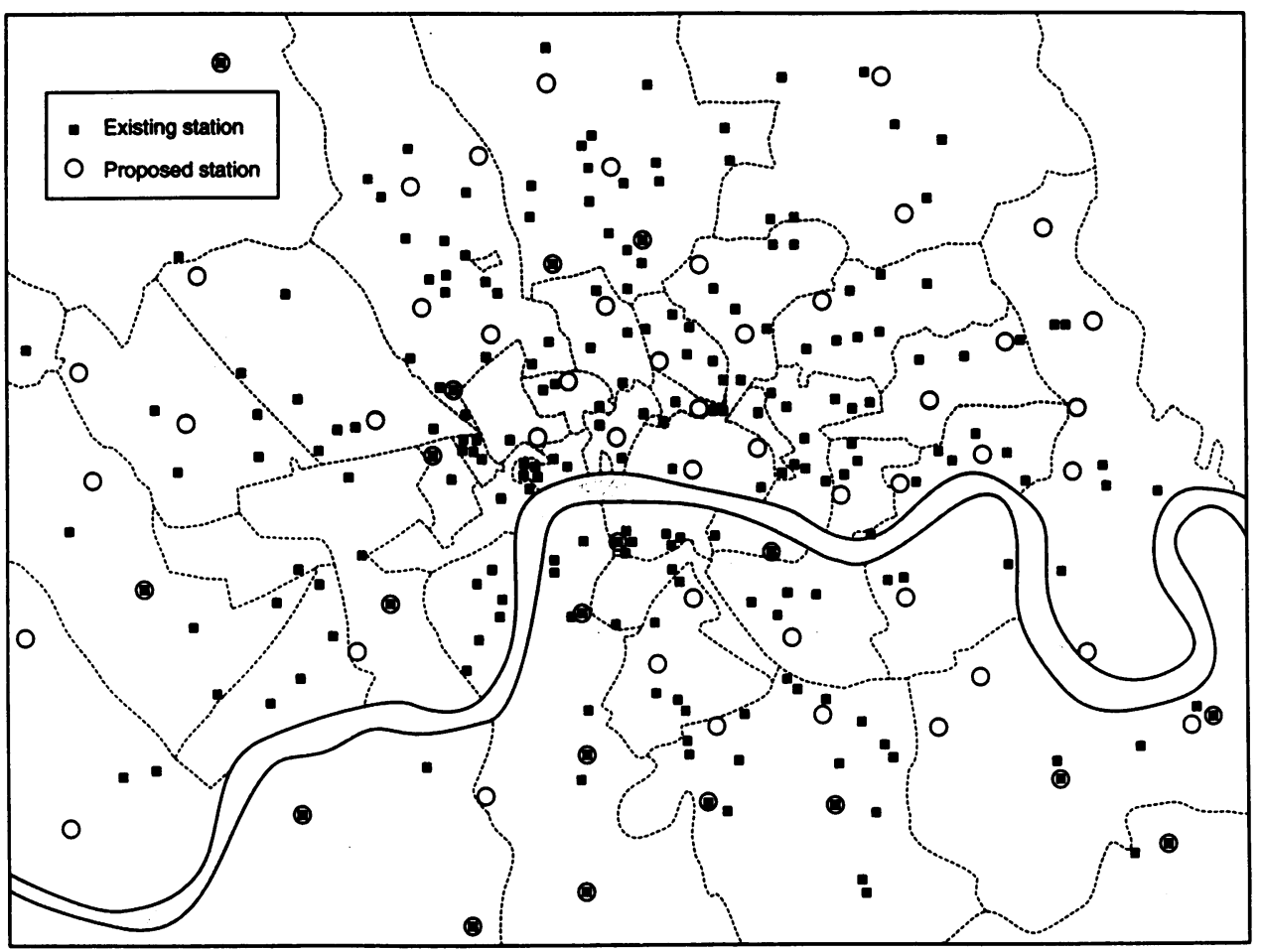

Source: $R M O P C, 1863$, following p.118

Figure 3: Existing and proposed vaccination stations, London unions, 1863

4. Supervising the duties of the registrar.

5. Issuing public notices.

6. Examination of the vaccination registers, through the appointment of a clerk. This clerk would also issue quarterly lists of the vaccinations chargeable to each parish. Each parish would be rated according to its population, and a central fund would exist to meet all charges.

7. Supervision of parental responsibility. This included the systematic return of children for inspection and the supply of fresh lymph. Inspectors with authority over a specified quota of sub-districts would be employed to ensure the registration of births and warn parents of their responsibilities.

8. Take emergency action during smallpox epidemics, such as issuing warnings, and providing for more vaccination and re-vaccination. ${ }^{85}$

${ }^{85}$ RMOPC, 1863 , op. cit., note 44 above, pp. 118-20. 


\section{Graham Mooney}

The most important aspect was that this agency would be both dissociated from the stigma of parochial relief and independent of minor local influence and interests. We should not be surprised at this outcome to the report, which presented a powerful case for the central control of vaccination administration in the metropolis.

In the event, there was a parochial rationalization, undertaken in 1868 by the Poor Law Board, which reduced the number of unions in the capital from 39 to 30 and the number of public vaccinators to 134 . By the time a Parliamentary review of the 1867 Vaccination Act was conducted, Seaton argued that "a very great deal of London is now very much upon the principle which we proposed". ${ }^{86}$ Although evidence that the proportion of smallpox mortality occurring in the 1-4 age group was declining seems to bear out Seaton's claim that the Act had been successful, ${ }^{87}$ Table 5 illustrates that a number of districts in London suffered very high levels of smallpox mortality in 1871. These particular mortality rates hold two significant advantages over and above the mortality data published for registration districts in the $A R R G s .^{88}$ First, they are the only annual rates available for the component districts of the metropolis broken down in any way by age-although a very limited number of $\mathrm{MOH}$ annual Reports gave such data and the Registrar-General's decennial Supplements do provide ten-year totals by district. ${ }^{89}$ Second, the smallpox deaths occurring in the several metropolitan asylum fever hospitals and the smallpox hospitals were redistributed back to the original district of residence of the deceased. ${ }^{90}$ The historical importance of these rates should not therefore be underestimated. We can see that the impact of the 1871 epidemic on the under-fives was especially severe in St George Hanover Square in west London, Shoreditch and Bethnal Green in the east end, and Wandsworth and St Saviour Southwark south of the river Thames. The mortality rates in some of these districts were more than ten times the national rate and the fact that the amount of public vaccination had not increased since the

\footnotetext{
${ }^{86}$ Report from the Select Committee on the Vaccination Act 1867, PP 1871, xiii, p. 306. Lambert notes that criticism of this policy was forthcoming from the Lancet, the PLMÓs and William Farr. See Lambert, op. cit., note 42 above, p. 445.

87 The proportion of total national smallpox mortality occurring in the under-five age group fell from 55 per cent in 1867 , to 34 per cent in 1870 and 30 per cent in 1872 . Seaton also claimed that of the metropolitan districts in 1871-72, only in Bethnal Green did this proportion "remain at the average of the period preceding the Act of 1867". In all the others, the proportion was below. This probably refers to the ten years $1851-60$, since the only mortality data giving under-five mortality by district appears in the Registrar-General's decennial Supplements. See Mooney, op. cit., note 67 above, pp. 199-200 and Figures 8.7 and 8.8. The greater proportion of adults dying from smallpox was often used as an argument for the value of revaccination at puberty.

${ }_{88}$ Mention should be made of the method used to calculate the mortality rates shown in Table 5.
}

Smallpox deaths in E C Seaton, 'On the recent epidemic of smallpox in the United Kingdom, and its relation to vaccination and the vaccination laws', Report of the Medical Officer of the Privy Council and Local Government Board, 1874 (henceforth RMOPCLGB), PP 1875, xl, Appendix 5, are given for the under-five age group and all ages. For the under-fives, the population at risk used for each registration district, London and England and Wales, is that given in the 1871 census. However, because some babies born in 1871 will have died before the census enumeration, the under-one age group is subtracted and replaced with the total number of live births in that year, taken from the 34th ARRG, 1871, op. cit., note 1 above, p. 32.

${ }^{89}$ See B Luckin and G Mooney, 'Urban history and historical epidemiology: the case of London, 1860-1920', Urban Hist., 1997, 24 (1): 37-54.

90 On London's "redistribution" problem, see N Williams and G Mooney, 'Infant mortality in an "Age of Great Cities": London and the English provincial cities compared', Continuity and Change, 1994, 9: 185-212, pp. 188-90. 


\section{Smallpox Vaccination in Nineteenth-Century London}

Table 5

Public infant vaccination rates per 1,000 live births, $1870,{ }^{1}$ and smallpox mortality rates per 100,000 population, 1871 , in London registration districts

\begin{tabular}{|c|c|c|c|c|}
\hline & & Mortality rate & & \\
\hline District $^{2}$ & IVR & Under 5 Over 5 & District & IVl \\
\hline
\end{tabular}

West London

Paddington $\quad 313$

Kensington ${ }^{3} \quad 212$

Fulham $\quad 384$

Chelsea 462

St George Hanover Sq 644

Westminster 249

Marylebone $\quad 332$

\section{East London}

$\begin{array}{llll}\text { Shoreditch } & 411 & 1,304 & 298\end{array}$

Bethnal Green $\quad 430 \quad 1,571 \quad 235$

$\begin{array}{llll}\text { Whitechapel } & 641 & 968 & 192\end{array}$

St George-in-the-East $397 \quad 594 \quad 143$

$\begin{array}{llll}\text { Stepney } & 452 & 457 & 162\end{array}$

$\begin{array}{llll}\text { Mile End Old Town } \quad 386 & 558 & 168\end{array}$

$\begin{array}{llll}\text { Poplar } & 444 & 427 & 144\end{array}$

North London

Hampstead

Pancras

Islington

Hackney

Central London

St Giles

Strand

Holborn

London City

$\begin{array}{lll}157 & 288 & 208 \\ 285 & 861 & 265 \\ 159 & 467 & 176 \\ 163 & 848 & 246\end{array}$

\section{South London}

$\begin{array}{lrrr}\text { St Saviour Southwark } & 392 & 1,086 & 250 \\ \text { St Olave Southwark } & 378 & 677 & 189 \\ \text { Lambeth } & 374 & 519 & 199 \\ \text { Wandsworth } & 301 & 1,088 & 270 \\ \text { Camberwell } & 399 & 433 & 148 \\ \text { Greenwich } & 473 & 285 & 71 \\ \text { Lewisham } & 4 \\ \text { Woolwich } & 388 & 61 & 47 \\ & & 200 & 45 \\ \text { London total }^{5} & 417 & 673 & 179\end{array}$

England and Wales

129

98

Sources: W H Smith, Vaccinations (Metropolitan districts), PP 1871, lix, p. 505; RMOPCLGB, 1874 , p. 79 . See note 88 in the main text for the method used to calculate these mortality rates.

Notes:

${ }^{1}$ year ended 29 September 1870.

2 notes 3 to 9 on Table 3 detail the parochial composition of the registration districts.

${ }^{3}$ the smallpox deaths for the under-fives in Paddington, Kensington and Chelsea Poor Law unions were combined to provide the figure for the Kensington registration district.

4 includes vaccinations in Woolwich.

5 of the total 7,982 smallpox deaths registered in London in 1871, 30 were to persons who lived outside the capital. The precise districts where these deaths were recorded are not given. 


\section{Graham Mooney}

Seaton and Buchanan inquiry was obviously a significant factor in accounting for this. In 1860-62 the public IVR for London stood at 417 per 1,000 live births, rising to 517 per 1,000 during the epidemic period 1862-63 (see Table 3 above). ${ }^{91}$ Table 5 shows that by 1870 , even following the tightening up of the compulsory provisions and the rationalization of the Poor Law unions, the position was actually worse than at the time of Seaton and Buchanan's report, with a relatively meagre metropolitan public IVR of 321 per 1,000. To explain fully the range of values observed across London would of course require intensive local research. Seaton himself drew attention to the example of St George Hanover Square. Even though it possessed a high public IVR in 1870, the excessive mortality rate for the under-fives was due to the recent incorporation of St Mary and St John Westminster union which had not taken any steps to execute the 1867 Vaccination Act. ${ }^{92}$ Under this legislation, the appointment of the vaccinating officer by the Guardians was purely permissive and a number of unions were slow to secure one. ${ }^{93}$

Table 6-which calculates from the VO returns the level of total vaccination rates (i.e. both public and private vaccination) for the period 1872 to 1890 -provides an additional angle to the one displayed in Table 5. The IVR level in London remains below the national figure throughout, but the pattern over the capital is still a complex one. Some of the poorest parts of London-Poplar, Whitechapel, St Olave Southwark-returned a rather impressive degree of vaccination coverage on a fairly consistent basis. Comparing the figures for public vaccinations in 1871 in Table 5 with those for total vaccinations in 1872 in Table 6, it is impossible to gauge whether the implementation of the 1871 Vaccination Acts had any significant impact upon the level of public vaccination locally, although Table 4 above was highly suggestive on this point. Doubtless the figures in Table 6 represent a fair amount of "topping up" of public vaccination by private operations which were considered inefficient, as we have already seen. The Medical Department at the LGB was also interested in eliminating the residual 10 per cent or so of "missing" infant vaccinations in London. Initial confidence expressed by Seaton in the early 1870 s that this percentage would lessen when some lax unions eventually appointed VOs, and once the proficiency of the existing VOs had been heightened, was not convincingly borne out by the evidence of subsequent years. ${ }^{94}$ It was believed that the obstacle to complete vaccination coverage that was presented by a highly migratory population-as was the case in the poorer districts listed above-could be largely overcome by the work of a diligent VO. Yet the fact that after a birth many families regularly moved between London unions before the three months allowed for vaccination had expired, thus escaping vaccination, remained a constant concern. ${ }^{95}$ In his investigation of the 1881 epidemic, Stevens concluded that the high rates of smallpox mortality in the unvaccinated "would seem to imply (1) faults in the machinery for the provision of vaccination, or (2) defective administration of that machinery-possibly both". He was particularly struck with the 52

\footnotetext{
91 The figures are taken from, Return of the number of vaccinations for the year ended 29 September, 1870, PP 1871, lix, p. 505.

92 Seaton, op. cit., note 88 above, p. 78.

93 Shortly before the outbreak of smallpox in 1871 , the clerk of St George Southwark was alleged to have commented that, “[w]e've done nothing, Sir, and we don't intend to do anything". Ibid.
} 


\section{Smallpox Vaccination in Nineteenth-Century London}

Table 6

Total infant vaccination rates per 1,000 live births in London Poor Law unions, 1872-90

1872

1875

1880

1885

1890

Union

West London

Paddington

Kensington

Fulham

Chelsea

St George Hanover Sq

Westminster

Marylebone

North London

Hampstead

Pancras

Islington

Hackney

Central London

St Giles

Strand

Holborn

London City

East London

Shoreditch

Bethnal Green

Whitechapel

St George-in-the-East

Stepney

Mile End Old Town

Poplar

South London

St Saviour Southwark

St Olave Southwark

Lambeth

Camberwell

Greenwich

Lewisham

Woolwich

London total

England \& Wales
Wandsworth \& Clapham
885

932

898

919

949

929

864

876

843

916

852

853

918

928

936

877

891

907

786

890

897

921

$\begin{array}{ll}891 & 862 \\ 944 & 949 \\ 856 & 883 \\ 943 & 955 \\ 900 & 888 \\ 943 & 919 \\ 973 & 976 \\ 948 & 944 \\ 899 & 895 \\ 939 & 946\end{array}$

775

885

900

911

835

839

918

871

928

856

912

867

840

878

881

939
913

958

931

934

943

933

914

963

919

898

928

888

899

924

965

863

928

975

921

891

917

956

955

929

906

890

900

935

944

941

944

926

937

870

912

919

928

956

850

915

921

827

893

708

797

916

859

$915 \quad 885$

Sources: $R M O P C L G B$ and $R M O L G B$

Note: These rates are calculated by subtracting from the number of live births those unvaccinated infants who died before the end of the legally-defined three month time limit. 


\section{Graham Mooney}

per cent of the 1,125 deaths to children under the age of 15 whose district of death was not that in which they were born. He thus argued that "such escape was in numerous instances the outcome of the divers and too numerous local governments into which the administration of the Vaccination Acts in the metropolis is broken up". 96

A succession of medical inspectors, then, consistently argued that smallpox epidemics would have been far less severe had there been an overarching vaccination authority in London. Their calls were only partially heeded. The situation in the 1860 s was mollified to a certain extent by the MAB, with 15 nominees from the LGB and 45 representatives of the Boards of Guardians. Created through the Metropolitan Poor Act of 1867, the Asylums Districts were formed through combining some unions, in which hospitals accommodated paupers suffering from smallpox or fever. The cost for each patient was charged to the parish, whilst the hospitals themselves were maintained by a general fund. Nevertheless, because of the location of the hospitals, the MAB arrangements were found to be inadequate during epidemics, since "it would seem that they merely exist at the sufferance of the neighbourhoods in which they are placed; and under the terrifying influence of an epidemic may be summarily closed, leaving the disease to run its course uncontrolled, and London to take the consequences."97 Although further spatial reorganization undertaken after the passing in 1871 of the Vaccination Act and Local Government Board Act also followed the earlier proposals of Seaton and Buchanan, ${ }^{98}$ the LGB maintained that in epidemic periods, authority should pass from the hands of the Boards of Guardians and be placed centrally into those of the MAB, not only for the provision of hospital accommodation, but also for complete jurisdiction over smallpox control and vaccination. In giving evidence to the Royal Commission in 1882, Stevens argued that rather than have the MAB act, as it did, through the conflicting interests of the Boards of Guardians, it should have but "one head with numerous arms and legs", which would be able to instruct the Boards. ${ }^{99}$ The LGB would declare an "epidemic" and thus at a stroke remove the powers of the Boards of Guardians, who were considered by Stevens to be obstructive. The epidemic regulations would not apply to single districts but to the whole city, so eliminating the likelihood of persons moving across union boundary lines in order to avoid house-to-house visits, for example. Union distinctions would remain in order to preserve the districts for the vaccinating officers, but local inspections could be carried out by inspectors appointed by the MAB. The main body of this plan repeated the proposals of the 1877 Public Health (Metropolis) Bill ${ }^{100}$ which had aimed at consolidating for the metropolis no less than 11 various sanitary acts that had been repealed by the 1875 Public Health Act (from which the capital had been exempted). Concern centred around those clauses handing the LGB special powers which were in direct opposition to those of the vestry. ${ }^{101}$ Due to the political leverage wielded by the combined Parliamentary lobbying power of the vestries, district boards and $\mathrm{MBW}$, it became impossible to enact a

\footnotetext{
96 Stevens, op. cit., note 80 above, p. 50.

${ }^{97}$ Royal Commission on Smallpox and Fever Hospitals, PP 1882, xxix, p. vii. The problem of smallpox hospitals is discussed in Hardy, op. cit., note 5 above, pp. $137-42$.

98 The Vaccination Act 1871 (see note 49 above); The Local Government Board Act 1871 (34 \& 35 Vict. c. 70).
}

\footnotetext{
${ }^{99}$ Stevens, op. cit., note 39 above, p. 195.

${ }^{100}$ Public health (Metropolis) bill, PP 1877, v, pp. 541-87.

${ }^{101}$ Editorial, 'Public health Metropolis bill', Sanit. Rec., 20 July 1877, 7: 42. Upon complaint against a local sanitary authority, the LGB could order that authority to enforce the provisions of the legislation.
} 


\section{Smallpox Vaccination in Nineteenth-Century London}

Bill containing more than 100 clauses which had been introduced so late in the Parliamentary session. A report made by the Parliamentary Committee of the MBW had interpreted the proposed new role of the LGB in the capital as "a serious step towards centralization in local government", and accordingly instructed the vestries and district boards to take immediate steps against the Bill. ${ }^{102}$ Partly as a result of this recommendation, the vestries and district boards unanimously petitioned the House of Commons on three basic grounds: first, the LGB had only once used the powers vested in it by the 1871 Local Government Act, thus obviating the need to re-enact these powers; second, some clauses, such as the one referring to "epidemic diseases", were ambiguous in their wording and were open to differing interpretation; third, they objected to the fact that the second reading of the Bill took place before it was printed, and that they had had little opportunity to consider the full implications of the legislation. ${ }^{103}$ Vestry pleas for the Bill to be delayed were merely blocking manoeuvres to legislation which threatened their autonomy in local public health matters, especially since the proposed authority for taking away this freedom was the LGB, the attitude of which was considered by the local sanitary authorities to be, "obnoxious to nearly all those with whom they have had any official business". ${ }^{104}$ The Bill was therefore withdrawn on 19 July 1877, although Sclater-Booth promised that were he to introduce the Bill in future, then it would be in an amended state. $^{105}$

It was not until April 1884 that the first Government-sponsored Bill to rationalize London's sanitary management was introduced by Sir William Harcourt, the Home Secretary. Notably, it embodied many of the proposals outlined by Orme Dudfield in his presidential address to the Society of Medical Officers of Health in $1883 .{ }^{106}$ The London Government Bill of 1884 planned to transform the City Corporation into a governing body for the whole of London. ${ }^{107}$ Local districts would be directly elected, and possess no powers other than those directed by a central authority, which was to be a Common Council of 240 members; and the Council would elect the Lord Mayor. In the first instance, the MBW was to be absorbed by the Common Council, but would later be directly elected by the ratepayers. As Robson notes, "[t]his was an obvious attempt to conciliate both the City Corporation and the Metropolitan Board of Works". 108 Nevertheless, Harcourt's Bill met with opposition from the Corporation, who were able to arouse dissenting support against the measure during the three months it took for a general debate to take place in the House of Commons. ${ }^{109}$ Although Orme Dudfield had naively supposed that objection might simply be to do with the nomenclature of the new central

\footnotetext{
102 Editorial, 'Public health Metropolis bill', Sanit. Rec., 6 July 1877, 7: 7.

103 Editorial, 'Public health Metropolis bill', Sanit. Rec., 20 July 1877, 7: 38-39.

104 Editorial, 'Public health Metropolis bill', Sanit. Rec., 27 July 1877, 7: 56.

105 G Sclater-Booth, Hansard's Parliamentary Debates, 3rd Series, 19 July 1877, House of Commons, col 1,534.
}

\footnotetext{
106 Orme Dudfield, op. cit., note 17 above.

107 Bill for better government of London, PP 1884, v, pp. 115-16.

${ }^{108}$ Robson, op. cit., note 13 above, pp. 73-4. The immediate cabinet wranglings leading up to this measure can be found in Young and Garside, op. cit., note 21 above, pp. 39-63.

109 Young and Garside, op. cit., note 21 above, pp. 48-51.
} 


\section{Graham Mooney}

authority, ${ }^{110}$ Robson has shown that the City Corporation was afraid of losing more than just its name. In 1884 alone, a Special Committee of the Court of the Common Council spent no less than $£ 14,139$, "for the purpose of influencing Parliament by misrepresenting the state of public opinion". ${ }^{111}$ After all, did not the summary of the Bill state categorically in one chilling sentence: "There will be no aldermen"? 112

Evidently, any proposed legislation had to appease both the vestries and the City Corporation. In the 1877 Bill, the constitution of the City Corporation had remained unaffected, but the authority of the vestries, district boards and the MBW was undermined. In 1884, the very existence of the Corporation was threatened. Although at the time it was reported the MBW had agreed in principle to "the necessity of one central jurisdiction for the whole metropolis", 113 it still believed that the vestries were the best executive bodies for enacting legislation at the local level and eventually convened a vestry conference to condemn the Bill. ${ }^{114}$ Second, it was recognized that whilst the creation of a new sanitary administration and the consolidation of sanitary laws should be mutually dependent, the former was a necessary pre-requisite of the latter. As Orme Dudfield pointed out, no doubt foreseeing the failure of the 1884 legislation, "there is little reason to anticipate the grant of such powers [to control the spread of infectious diseases through notification, isolation and disinfection] until a strong central sanitary authority shall have been created by which the action of the several local sanitary authorities may be combined for the common good". ${ }^{115}$ The smallpox proposals of the Royal Commission were finally implemented in July 1884 , when the MAB took control of the ambulance service and the smallpox hospitals were removed from their central locations. The stringent regulations of the Port Sanitary Authorities, especially from 1885, were also critical in limiting the entry of the disease into the capital from other national and international ports. ${ }^{116}$ Notification of smallpox followed before the end of the decade, and coupled with the detailed isolation of infected cases, the re-organization enabled reasonably efficient prevention and eradication from London in the 1890 s, at a time when the disease showed itself not only on the continent, but in Sheffield, Bristol and

\footnotetext{
${ }^{110} \mathrm{He}$ recognized that for nostalgic reasons the new central authority might "become in fact as in name the Corporation of London", but practical evidence of the work carried out by the MBW suggested that the new authority should adopt the title of that body. Orme Dudfield, op. cit., note 17 above, pp. 237-8.

111 Robson, op. cit., note 13 above, p. 77. Following the announcement in the Queen's speech of the intention to reform the Corporation, the Special Committee spent a total of nearly $£ 20,000$ between 1883 and 1885 .

${ }^{112}$ London government bill summary, PP 1884, v, p. 2. On the Corporation's opposition to Harcourt's Bill, see T B Smith, 'In defense of privilege: the City of London and the challenge of municipal reform', $J$. soc. Hist., fall 1993: 59-83, on pp. 66-9.
}

\footnotetext{
113 Editorial, 'The London government bill', Sanit. Rec., 15 May 1884, NS 5: 548. The journal itself was of the conviction that " $[\mathrm{t}]$ he composition of the vestries has except in a few districts where public opinion has recently quickened, steadily retrograded. The new central council may be fairly expected to attract men of a distinctly higher mental character than those who now compose the Corporation and the vestries; and gradually the whole tone of municipal life will thus be raised".

114 Only one vestry supported the Bill. See Davis, op. cit., note 20 above, pp. 78 and 81 .

${ }^{115}$ Orme Dudfield, op. cit., note 17 above, pp. 235-6.

116 Hardy, op. cit., note 28 above, p. 115; idem, op. cit., note 5 above, pp. 141-2.
} 


\section{Smallpox Vaccination in Nineteenth-Century London}

Manchester, too. ${ }^{117}$ Anne Hardy has recently commented upon the eventual effectiveness of this "complete preventive package" for smallpox in London, describing it as "perhaps the most successful face of the new preventive medicine". ${ }^{118}$ Unfortunately, subsequent legislation on the wider administrative stage ultimately failed to live up to the hopes of the public health professionals. Although the 1888 Local Government Act transferred nearly all the powers of the MBW to the LCC, it left the vestries and the district boards virtually untouched as the primary bodies. ${ }^{119}$ The Corporation retained the majority of its public health functions, other than provision of the main drainage, and the MAB maintained its responsibility for the hospital accommodation of the sick poor. As such the Act "did not even pretend to solve the problem of London government", 120 and the vestries and district boards awaited the fate brought to them by the 1899 London Government Act, which reorganized the capital into 28 Metropolitan Boroughs. ${ }^{121}$ In legislative terms, the Public Health (London) Act of $1891^{122}$ finally accomplished what the 1877 Public Health (Metropolis) Bill had failed to do, namely consolidate the majority of the existing sanitary laws relating to London, although executive responsibilities were somewhat arbitrarily sub-divided between the LCC and the vestries, and smallpox vaccination was ignored altogether.

\section{Conclusion}

In the mid- and late-nineteenth century, London's rates of smallpox mortality were generally higher than those of England and Wales. This paper has suggested that the main reason for this was the inefficient management and implementation of compulsory vaccination in London, rather than simply ideological objections from the general public (although the inefficiencies of the vaccination system in London would have offered the opportunity for a more concealed opposition than elsewhere in the country). This particular critique is valuable for two interrelated reasons. First, throughout the second half of the nineteenth century, information concerning the levels and trends of mortality and sickness were increasingly used as evidence to justify state intervention to improve both public and private health. ${ }^{123} \mathrm{~A}$ prime example of this is the extensive range of material concerning smallpox vaccination collected by the medical profession on behalf of the state and deployed in debates about the operation's efficacy, administration and epidemiological impact. No doubt, this can be interpreted as part of the wider

\footnotetext{
117 A Wilkinson (now Hardy), 'The beginnings of disease control in London: the work of the medical officers in three parishes, 1856-1900', DPhil thesis, University of Oxford, 1980, p. 161; Hardy, op. cit., note 5 above, pp. 147-50. During the 1893 epidemic, London's mortality rate stood at 7 per 100,000 population, compared to 67 in Sheffield, 91 in Manchester and 99 in Bristol. These rates are calculated by the method used in Figure 1 (see note 28 above) and are taken from the tables contained in the 56th ARRG, 1893.

${ }_{118}$ Hardy, op. cit., note 5 above, p. 111.

119 They did, however, become responsible for the payment of half the salary of their MOH. Local
}

Government Act 1888 (51 \& 52 Vict. c. 41).

${ }^{120}$ Robson, op. cit., note 13 above, p. 81 .

121 London Government Act 1899 (62 \& 63 Vict. c. 14).

122 Public Health (London) Act 1891 (54 \& 55 Vict. c. 76).

${ }^{123}$ See G Mooney, 'The prevention and control of infectious childhood diseases in late nineteenth- and early twentieth-century London: the case of diphtheria and measles', in R King and M L Gentileschi (eds), Questioni di popolazione in Europa: una prospettiva geografica, Bologna, Pàtron, 1996, pp. 255-71. 


\section{Graham Mooney}

"medicalization" of society. Through the epidemiological investigations of doctors such as Seaton and Buchanan, by the mid-nineteenth century, "we begin to see", in the words of Christopher Lawrence, "the creation of a new medical science of disorder, the promotion of medically informed solutions and the advancement of the claims of the medical expert. Within this science, detailed knowledge of the biology, pathology and epidemiology of disease were deemed the foundations of action". ${ }^{124}$ Smallpox vaccination provided a perfect example of this, becoming the medical basis for an argument which advocated the administrative simplification of "sanitary" London. This leads naturally into the second feature of the critique. Because of the unique structure of its sanitary legislation and executive, London provides a particularly interesting case study from an administrative-bureaucratic viewpoint. The lack of central control over all the preventive legislation in the capital, and the failure to introduce consolidating measures, meant that in most sanitary matters essentially local problems were dealt with by locally developed solutions. While the want of administrative unification primarily underlay the poor performance of vaccination in London in the 1850 s and 1860 s, it should also be emphasized that the most undermining aspect was the inextricable link of vaccination with the Poor Law authorities. This relationship struck far deeper than the inefficiency typified by spatial sub-division at the parochial level (the vaccination station problem being the most glaring example); or of the fearful public perception surrounding the stigma of association with the Poor Law, which not only caused evasion, but also led to higher levels of (largely inefficiently-performed) private vaccination in London, where there was a greater concentration of wealth than elsewhere in the country. Most significantly, because vaccination was the sole preserve of the already highly-centralized Poor Law administration, the arguments put forward for the overhaul of the service failed to influence the wider political debate concerning the consolidation of London's government. With the vestries and the City Corporation persuasively lobbying central government against rationalization, most public health responsibilities remained entirely in the hands of the metropolitan MOHs. It is arguable that in the absence of a centralized sanitary authority or legislation, smallpox would probably have proved less of a threat to the life of Londoners had the vaccination service also been under their jurisdiction.

${ }^{124} \mathrm{C}$ Lawrence, Medicine in the making of modern Britain, 1700-1920, London, Routledge, 1994, p. 50. 